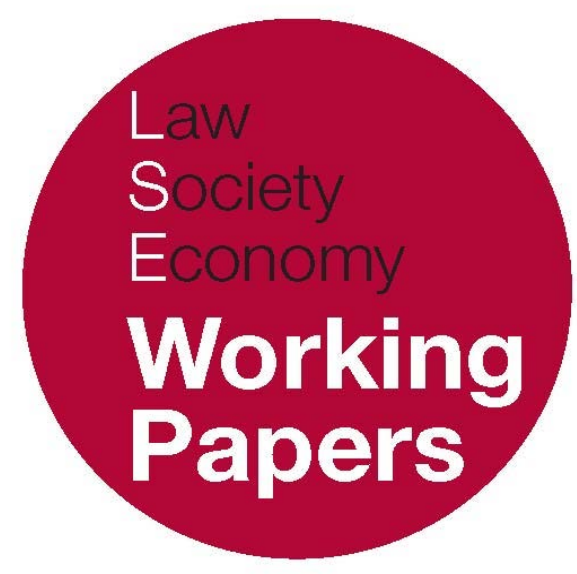

\title{
Economic Messianism and Constitutional Power in a 'German Europe': All Courts are Equal, but Some Courts are More Equal than Others
}

\author{
Michael A. Wilkinson \\ LSE Law, Society and Economy Working Papers 26/2014 \\ London School of Economics and Political Science \\ Law Department
}

\begin{abstract}
This paper can be downloaded without charge from LSE Law, Society and Economy Working Papers at: www.lse.ac.uk/collections/law/wps/wps.htm and the Social Sciences Research Network electronic library at: http://ssrn.com/abstract=2522919.

(C) Michael A. Wilkinson. Users may download and/or print one copy to facilitate their private study or for non-commercial research. Users may not engage in further distribution of this material or use it for any profit-making activities or any other form of commercial gain.
\end{abstract}




\title{
Economic Messianism and Constitutional Power in a 'German Europe': \\ All Courts are Equal, but Some Courts are More Equal than Others
}

\author{
Michael A. Wilkinson*
}

\begin{abstract}
Since the financial crisis there have been extraordinary efforts by the European Central Bank to protect the single currency, alongside pronouncements by European political elites that the Euro determines Europe's fate and must be rescued at any cost. This Economic Messianism is challenged by the German constitutional court in its OMT reference, as violating the constitutional logic of the democratic Rechtsstaat. And yet, the German Court is also promoting an ordo-liberal logic of avoidance of moral hazard, fiscal competitiveness and austerity that undermines the project of European integration and erodes constitutional democracy in the debtor states. These tensions - between supranational economic integration, state sovereignty and domestic constitutionalism - reveal the depth of the constitutional disequilibrium in the EU, and also reflect broader contradictions in the development of late democratic capitalism.
\end{abstract}

\footnotetext{
* Associate Professor of Law, London School of Economics. Earlier versions of this paper were presented at the LSE - Paris II Public Law Seminar, and at National University of Singapore Faculty of Law. I would like to thank participants at both events, in particular Denis Baranger, Christoph Schönberger, Oliver Lepsius, Samuel Tschorne, Mike Dowdle, Christian Hofmann and James Penner. I would also like to thank Damian Chalmers, Christian Joerges, Nina Boeger and Cormac MacAmleigh for comments on an earlier draft. All errors are mine.
} 
'Can the buying of time with the magic of modern money - the periodic extension of the old promises of a socially pacified capitalism, long after they have lost their foundation in reality - continue in and after the great crisis of the early twenty-first century? Half a decade on from 2008, that is precisely what is being tested in a worldwide field experiment. The only money still available for it is the fiat money of the central banks; and the main authority left for the governance of oncedemocratic capitalism, now moving into its Hayekian phase, is the authority of the central bank presidents.' [Wolfgang Streeck, Buying Time: The Delayed Crisis of Democratic Capitalism (Verso, 2014) 165]

\section{INTRODUCTION}

Does the European Central Bank (ECB) have a mandate to do 'whatever it takes' to save the Euro? Not according to the German Constitutional Court, which earlier this year delivered its judgment from Karlsruhe on the ECB's Outright Monetary Transactions programme (OMT). ${ }^{1}$ Attention now turns to the European Court of Justice. Will it concur on the illegality of the bond-buying programme, or attempt to resist the might of the most powerful domestic court in Europe?

Through the OMT programme, the ECB had promised unlimited purchases on secondary markets of bonds from selected member states, signalling that it would act in effect as the Eurozone's conditional 'lender of last resort'. Although not triggered in practice, the availability of OMT apparently stabilised the Euro area, calming financial markets and reducing 'irrationally' high spreads on the sovereign bonds of ailing states. ${ }^{2}$

Whether or not the OMT was the 'big bazooka' that was called for, it was surely more than merely a water pistol, even if launched inconspicuously by the ECB in the form of a press release. ${ }^{3}$ Karlsruhe's challenge to it raised a number of questions: in highlighting the failure to obtain proper license for this weapon, has the German Court affected the fate of the Eurozone, and placed into jeopardy any long-term economic recovery? Has the dog finally bitten and in so doing

\footnotetext{
${ }^{1}$ Bundesverfassungsgericht [BVerfG - Federal Constitutional Court], 2 BvR 2728/13 (14 January 2014).

2 See C. Gerner-Beuerle and E. Schuster, 'Law Meets Economics in the German Federal Constitutional Court: Outright Monetary Transactions on Trial' (2014) German Law Journal 281 - 320, 282, who note it has been credited as 'one of the most effective announcements any central bank has ever made'. The rationality or otherwise of the spreads, a significant issue in the case, is dealt with below.

3 European Central Bank, Press Release 6 September 2012: Technical features of Outright Monetary Transactions, www.ecb.europa.eu/press/pr/date $/ 2012 / \mathrm{html} / \mathrm{pr} 120906$ 1.en.html. It was David Cameron, who, from the sidelines, suggested that a 'big bazooka' was required to help resolve the Eurozone crisis, see 'Time is Short for Eurozone, Says Cameron', Financial Times, 9 October 9, 2011. OMT has been described as 'Draghi's Bazooka', see 'Editorial Comments' 51 CML Rev (2014) 327 - 388.
} 
threatened to spread financial contagion? ${ }^{4}$ And if, as Chancellor Merkel has insisted, the survival of the EU is dependent on the fate of the Euro, has Karlsruhe thereby called into question the future of European integration itself? 5 The short answer to these questions is, 'only time will tell'.

In terms of its economic implications for the Eurozone, the significance of the judgment has so far been slight. The OMT may, in any case, have already served its purpose, without needing to be triggered, properly licensed or not.

But the earlier bark of a dog may deter the potential burglar. It cannot be discounted that the possibility, based on a reputation gained through earlier jurisprudence, of being legally challenged or undermined by the German Constitutional Court deterred Chancellor Merkel from intervening sooner and more decisively in the Euro crisis. ${ }^{6}$ Nor can the potential legal, political, and economic repercussions of the German court subsequently rejecting German involvement in OMT - following any future judgment by the Court of Justice - be ignored. This raises the further question of whether amendment to the German Basic Law can be deferred any longer if European integration is to stay its course. ${ }^{7}$

From a juridical perspective, the first ever reference from Karlsruhe to Luxemburg has caused quite a stir. And for the ECJ, the stakes remain high. Economically, the Eurozone is still fragile, even, on some accounts, facing a period of 'secular stagnation'. ${ }^{8}$ Although the financial markets seemed untouched by Karlsruhe's initial bark, Luxembourg's bite could be a wholly different matter. Although the German Court has provided the outlines of an escape route suggesting that if the weapon is rendered safe by judicial guarantees of limited purchasing, no debt restructuring and avoidance of market interference, then revocation of its official license may be unnecessary - this would, on all accounts, make the weapon entirely ineffective. ${ }^{9}$

Whatever Luxembourg's response, the challenge reveals a fundamental weakness at the heart of the EU's political constitution, or so it will be argued. As a result of the structure of economic and monetary union, the Euro is a 'currency without a state'. ${ }^{10}$ It is a currency with a asymmetric union of competitive states

\footnotetext{
${ }^{4}$ The German Court has been likened to a dog that barks but does not bite. See e.g. J. H. H. Weiler, 'The Lisbon Urteil and Fast Food Culture' (2009) 20 European Journal of International Law 505.

5 'If the Euro fails, so will the idea of European Union', Der Spiegel, 13 May 2010.

${ }^{6}$ As Franz Mayer puts it, as the Constitutional Court increasingly 'over-reaches', 'politicians increasingly try to anticipate' its 'sensitivities'. F. Mayer, 'Rebels without a Cause? A Critical Analysis of the German Constitutional Court's OMT Reference’ (2014) 15 German Law Journal, 111 -146, 135.

${ }^{7}$ Given that the Eternity Clause is in play, arguably even an amendment to the Basic Law would not be enough, but it would require a new constitution under an act attributable to the constituent power. See e.g. M. Kumm, 'Rebel Without a Good Cause: Karlsruhe's Misguided Attempt to Draw the CJEU into a Game of "Chicken" and What the CJEU Might do About It' (2014) German Law Journal 210.

8 See e.g. P. Krugman, 'Secular Stagnation in the Euro Area' New York Times, 17 May 2014: http://krugman.blogs.nytimes.com/2014/05/17/secular-stagnation-in-the-euroarea/? $\mathrm{php}=$ true\& type $=$ blogs\& $\mathrm{r}=0$.

${ }_{9}$ The already famous paragraph 100 of the decision. That this escape route leads only to a brick wall is argued by Schuster and Gerner-Beuerle, above note 2 .

10 This phrase is usually accredited to Italian economist and godfather of the single currency, Tommaso Padoa-Schioppa. For recent discussion, see M. Aglietta, 'A European Vortex' (2012) New Left Review 15 36.
} 
deprived of monetary sovereignty and among whom the avoidance of moral hazard - due to the 'irrationality' of helping thy neighbour - is raised into a sacrosanct principle.

And yet although lacking the organic and political bonds to guarantee its viability, the currency is deemed integral to the success of the project of integration, so much so that in times of crisis, emergency or 'non-standard' measures are effected for its rescue. If the Euro fails, Europe fails.

The Euro is a latter-day emblem of 'Economic Messianism', displacing the 'Political Messianism' of the founding fathers of European Union. ${ }^{11}$ Since the Euro is apparently the key to the survival of the EU, substitutes for political community emerge to rescue it, regarding OMT in particular, from a tense combination of the ECB, represented by its president, and a German ideology insistent on austerity as medicine for the ailing Euro area states. But a monetary project led by a technocratic institution and the reluctant German hegemon that is necessary to bolster its credibility is a poor substitute for the community of solidarity or identity that normally undergirds the fate of a polity.

In this configuration - a 'German Europe' - although political and economic powers have been ceded to supranational institutions, domestic constitutional power still continues to shape the European construct and is now testing the limits of its constitutional architecture.

But if national constitutionalism is the last bastion of resistance against the technocratic control of policies from above, this is a deeply uneven prospect: some courts are clearly 'more equal than others'. This raises the problem of what I call 'constitutional hazard'. Karlsruhe is able to use its leverage to place enormous pressure on the ECJ to follow its own judgment, raising the risk that the European construct will be determined by the constitutional power of a domestic court that speaks only on behalf of its constituency.

The background to Karlsruhe's first ever reference to the ECJ will first be sketched. It arises in a post-crisis context of increasing imbalance in the constitutional structure of the EU, now threatening to turn the principle of 'moral hazard' into a supra-constitutional norm (part 1). The OMT decision reveals another aspect of this imbalance, 'constitutional hazard', which arises because of Germany's particular domestic constitutional settlement (part 2). Karlsruhe - for all its methodological nationalism - cannot simply be feted for dutifully reasserting the Westphalian Rechtsstaat against a European 'Raison d'état' based on Economic Messianism, because the German Constitutional Court is also defending a substantive view of political-economic rationality that has its own Messianic vision of fiscal austerity, complemented by an unquestioned faith in the expertise of its Bundesbank (part 3). Looking beyond the specificity of OMT, the reference exposes a deeper constitutional disequilibrium in the $\mathrm{EU}$, between the logics of

${ }^{11}$ See J. H. H. Weiler, 'The Political and Legal Culture of European Integration: an Exploratory Essay' (2011) International Journal of Constitutional Law 678 - 694. 
supranational capital, Westphalian statism, and domestic constitutionalism, which in turn reflect broader trends in the crisis of democratic capitalism (part 4). These tensions will not be resolved by judicial ingenuity, but they can be aggravated by disingenuous reasoning and, therefore, the paper concludes, require delicate handling.

\section{CONSTITUTIONALISING MORAL HAZARD}

In the view of Karslruhe, OMT, as an act of economic rather than monetary policy, manifestly violates the distribution of power between the EU and the Member States. ${ }^{12}$ The basic framework of EMU was set up so that the EU, and more specifically its Central Bank, would have exclusive competence on matters of monetary policy, setting short-term interest rates for the euro currency with the primary goal of maintaining price stability (Article 127(1) TFEU). The Member States, subject only to soft-law methods of 'co-ordination' among them, would retain economic self-determination, setting their own policies on how to tax and spend, and supporting the general economic policies of the Union in accordance with principles of an 'open market economy with free competition'.13

The ability of Member States to borrow - and so to service their existing debts - would be determined by market forces, prompting them to maintain budgetary discipline, along with whatever else matters for financial markets and credit rating agencies. ${ }^{14}$ This higher-level ordo-liberal principle of market logic explains the 'no bail-out' provision in Article 125(1) TFEU, formalising the avoidance of what is referred to as moral hazard: with the promise of financial support from elsewhere, states would be de-incentivised from keeping strict fiscal discipline and market logic would be vitiated.15 With national fiscal liability therefore comes national fiscal responsibility, supposedly disciplined by the markets and buttressed (albeit weakly) by the stability and growth pact, which was violated almost immediately by France and Germany and under-enforced by the European institutions. ${ }^{16}$

This basic framework has significantly mutated as a result of the postfinancial crisis measures, including the twin pillars of the European Stability Mechanism (ESM) and the Fiscal Compact (TSCG), which provide conditional financial assistance to beleaguered Member States and heightened supervision over national budgetary autonomy respectively. And in Pringle the ECJ rationalised the

\footnotetext{
12 See Paras $63-69$.

13 Article 119 TFEU.

14 Albeit these are same rating agencies that confirmed the quality of Greek (and other) debt prior to the financial crisis.

15 Budgetary autonomy is an essential state task to be reserved to Germany, according to the Lisbon Treaty judgment of the German court itself, Lisbon Case, BVerfG 2 BvE 2/08, 30 June 2009.

16 See Case C-27/04 Commission v Council. This has now been significantly hardened by subsequent secondary legislation and the Fiscal Compact.
} 
legality of the former by suggesting that since the ESM belonged to the sphere of economic policy - because aiming at stabilisation of the euro area as a whole (rather than merely price stability), ${ }^{17}$ - it could be agreed outside the Union acquis as a matter of Member State competence, even though using Union institutions, in the 'grey area' between EU and international law. ${ }^{18}$

In giving its stamp of approval to ESM, Pringle effectively mandates austerity by insisting that it is the 'strict conditionality' of assistance - a requirement codified in the new Article 136 TFEU - that makes it compatible with the Treaty's market logic. ${ }^{19}$ It is the strict conditionality imposed on recipient states through the Memoranda of Understanding negotiated with the 'Troika' (ECB, Commission, and IMF) that mitigates any disincentive for fiscal probity that might otherwise arise through the promise of rescue programs, with their mutual assumption of risk. ${ }^{20}$ The avoidance of moral hazard has, in other words, been raised into a supra-constitutional norm: only by imposing austerity on national constitutions can financial rescue be made consistent with budgetary discipline. To put the point more forcefully, avoidance of moral hazard is elevated above maintaining even a semblance of democracy in the debtor states.

Because performing a similar function to ESM in some respects, ${ }^{21}$ the German Court is able to play Pringle to its own advantage. ${ }^{22}$ Because OMT, like ESM, was a matter of economic rather than monetary policy, the ECB had no competence to pursue it. ${ }^{23}$ In other words, the fact that OMT may indirectly affect the stability (and even composition) of the euro area is not sufficient to classify it as monetary rather than economic policy. The granting of what, in the German Court's view, amounts to financial assistance to Member States clearly constitutes economic policy, and also likely violates the prohibition against central bank financing of the budget, enshrined in Article 123(1) TFEU. ${ }^{24}$

${ }_{17}$ Case C-370/12 Pringle v. Government of Ireland and the Attorney General, 27 November, 2012, para 135.

${ }^{18}$ For detailed accounts of the post-crisis constitutional 'mutation' of the European Union, see A. Menendez, 'Existential Crisis of the European Union' (2013) German Law Journal 453 - 526 and K. Tuori and K. Tuori, The Eurozone Crisis: A Constitutional Analysis (2014, OUP) 117 - 249.

${ }^{19}$ Pringle, para 136.

20 The argument that since Member States will have to maintain budgetary discipline, there is no interference with market logic is dubious; the whole point of a program such as ESM is that it steps in when market participants dare not. For an argument that ESM constitutes a 'circumvention' of EU law, see J. Tomkin, 'Contradiction, Circumvention, and Conceptual Gymnastics: The Impact of the Adoption of the ESM Treaty on the State of European Democracy' (2013) German Law Journal 169 - 189. The Treaty was amended subsequently, to take account of ESM, using the simplified revision procedure provided for in Article 48(6) TEU, adding a new third paragraph to Article 136 TFEU.

${ }^{21}$ Cf. Schuster and Gerner-Beuerle, according to whom, despite the similarities, the differences between ESM and OMT are more significant, and viewing them as 'functionally equivalent is misguided.' Above, note 2 .

22 Case C-370/12 Pringle v. Government of Ireland and the Attorney General, 27 November, 2012. This distinction has been criticised as 'formalistic'. See P. Craig, 'Pringle: Legal Reasoning, Text, Purpose and Teleology' (2013) 20 Maastricht Journal 1, 5.

23 Paras 64, 65, 66.

${ }^{24}$ Paras $84-94$. 
Central to the German Court's reasoning is an insistence on 'price stability' that rules out such monetary financing of the budget. ${ }^{25}$ The current integration programme has designed monetary union as, in the Court's words, a 'community of stability', in which budgetary discipline is one of the fundamental rules. Price stability is not only a key principle in the German ordo-liberal worldview; it is also enshrined in the Treaty itself, in Article 119(2) TFEU. But another ordo-liberal principle - competitiveness - is a significant subtext of Karlsruhe's judgment: the German Court is concerned that OMT might place at a 'disadvantage' other Member States than those offered support, by reducing the relative spreads of those it is targeted towards. ${ }^{26}$ Competitiveness is promoted as a principle not only of the micro-economic constitution, but also its macro-economic sibling. ${ }^{27}$

European constitutional stability is not, therefore, the main concern. But how does this narrow conception of price stability - or even the less narrow concept of financial stability ${ }^{28}$ - relate to broader issues of normative, economic, and political stability? And stability, it must be asked, for whom? Is the exclusive prioritisation of price stability compatible with stability for the 'right reasons', as a Rawlsian might ask? It must not be forgotten that the Union is founded on the principles of democracy and the rule of law, and also must promote 'a high level of employment, the guarantee of adequate social protection, the fight against social exclusion, and a high level of education, training and protection of human health' (Article 9, TFEU); not to mention 'tolerance, justice and solidarity' (Article 2 TEU), the 'peace and well-being of its peoples' (article 3 TEU), and the principle of equality of its citizens (Article 9 TEU). These obligations must also be addressed in adequately judging the constitutionality of Union measures.

The construct of EMU as set out at Maastricht was clearly not fit for purpose and would require radical modification in the event of financial crisis if it was not to be left to crumble in the face of market forces and domestic democratic pressures. ${ }^{29}$ But modification has occurred not merely through formal or procedural inventiveness, circumventing the prohibition on bail-outs in Article 125 TFEU through ingenious legal reasoning; this circumvention has been pursued and legitimated on the basis of a particular economic ideology. The Court of Justice in Pringle, it has been argued, not only mandates conditionality (in effect

\footnotetext{
${ }^{25}$ See e.g. para 43

${ }^{26}$ See para 73.

${ }^{27}$ On the relation between the micro- and macro- constitutions, see Tuori and Tuori, note 18 above.

${ }^{28}$ Financial stability has been described as the 'elephant in the room' for the German Court. See Bruekers (2014) German Law Journal. The notion of financial stability of the 'euro area as a whole' was key to the ECJ's reasoning in Pringle, above note 22.

${ }^{29}$ Germany, willingly or not, of course benefited from years of the single currency and artificially low yields in the periphery - albeit in conjunction with its own self-imposed wage restraints and through export and debt bubbles facilitated by its own banks - and more recently from the implosion in parts of the Euro area and the relatively higher spreads on debtor states. On the spectacular convergence of spreads from 1996 despite the underlying heterogeneity of the Eurozone, see M. Aglietta, above, note 10 Aglietta also notes the role played by Schroeder's labour market reforms for German competitiveness, in contributing to the widening gulf in the Eurozone after 2003. Clause Offe refers to the imperative to consider this inter-dependence the 'moral calculus' of integration. See C. Offe, 'Europe Entrapped' (2013) European Law Journal.
} 
'austerity'), but also makes explicit 'the constitutional status of the curtailment of sovereignty which beneficiary states must accept as a price for financial assistance'. ${ }^{30}$

The Memoranda of Understanding negotiated by the 'Troika' with states in receipt of such assistance imposes strict micro-management of budgetary powers, and mandates specific reforms in areas where the EU would normally have limited competence, such as health, education, and industrial relations. This erodes any vestige of parliamentary democracy and, because the arrangements exist formally outside of the Treaties, the usual protections of fundamental rights and the rule of law can be sidestepped. The voting rights in ESM, to give another example, are weighted according to capital contributions, with political influence now formally and directly reflecting the financial strength of the Member States. ${ }^{31}$ Monetary policy - supposedly de-politicised - has now itself become politicised with the ECB taking on the role of economic government. The 'self-evident truth of price stability' as the focus of monetary policy has also 'suffered a severe blow'. ${ }^{32}$ The economic reality, in any case, is far removed from the inflationary fears that haunt the ordo-liberal imagination.

This is not only a question of negotiating - or de facto imposing economically and politically controversial constraints on vulnerable nations; it is a question of formalising a new balance, or more likely, an imbalance of constitutional powers, moving from a Community to a Union method that is in danger of circumventing normative and democratic principles of selfdetermination. ${ }^{33}$ Democracy itself has been effectively suspended in the debtor states, even if this abrogation has been self-imposed, endorsed by domestic political elites despite serious popular discontent, and in some cases, violence and social unrest. ${ }^{34}$ There is little indication that these are temporary phenomena and that normality will shortly be restored. Constitutionalising moral hazard means that austerity is here to stay.

And if the architecture of EMU has constitutionalised austerity by conditioning support to ailing Member States, the German court's insistence in OMT on market logic does nothing to assuage this; it only reinforces an economistic trend, which prizes fiscal discipline above all else, without regard to the totality of the European constitution and the values of domestic political community.

\footnotetext{
30 Tuori and Tuori, above note 18.

${ }^{31}$ See Dawson and De Witte, 'The Constitutional Balance of the EU after the Euro-Crisis' (2013) Modern Law Review, 817.

32 Tuori and Tuori, above note 18 , at $186-187$.

33 See the editorial, 'Europe speaking German' (2012) European Constitutional Law Review 8, 1 - 8: 'The Fiscal Compact $[\ldots]$ strikes at the heart of the institutions of parliamentary democracy by dislocating as a matter of constitutional principle the budgetary autonomy of the member sates', 5. See also Menendez, above note 18 .

34 It is not only systematic violation of the rule of law that is threatened, but basic principles of democratic self-determination.
} 


\section{MORALISING CONSTITUTIONAL HAZARD}

'Today the German Bundestag will decide the fate of Greece', learnt Ulrich Beck with a mixture of resignation and incredulity, when the second 'rescue package' for Greece was announced in February 2012.35 Two years later, and the German Bundesverfassungsgericht in its OMT reference calls into question the fate of the Euro, but passes the ticking bomb to the European Court of Justice to detonate.

The German Constitutional Court's first ever use of the preliminary reference procedure, although anticipated by Honeywell, is noteworthy in itself. ${ }^{36}$ But Karlsruhe has an extra card up its sleeve, to the effect that not only is the act of the ECB manifestly and significantly ultra vires, it would also constitute a violation of 'national constitutional identity', specifically the right to vote in the Bundestag, indirectly protected via the principle of democracy by the 'Eternity Clause', article 79(3) GG. ${ }^{37}$ Does this mean that OMT is caught between the rock of ultra vires according to EU law and the hard place of unconstitutionality on the basis of core German constitutional identity?

Separating these two points is far from straightforward. ${ }^{38}$ Their combination into this one challenge and referral to the ECJ means that even if the ECJ interprets the OMT decision in a manner compatible with EU law - but in a manner distinct from that offered by the German Court in paragraph 100 - or otherwise rules against it being ultra vires, the measure could still fall foul of German constitutional exceptionalism. ${ }^{39}$ It would suggest that even a Treaty change to expressly allow for OMT would not be permitted by the German constitution. Thus Karlsruhe is able to use its leverage to place enormous pressure on the ECJ to accord with its own judgment of the situation in general and the illegality of OMT in particular. This time the dog has undoubtedly 'bitten' and not merely barked, as had arguably been the case in its earlier and infamous jurisprudence on the Maastricht and Lisbon Treaties. ${ }^{40}$

On the one hand, this German 'bite' is problematic because it blurs the boundaries between the two legal orders, national and European. According to

\footnotetext{
35 See U. Beck, German Europe (Cambridge, Polity, 2013) 1.

362 BvR 2661/06 Honeywell, Judgment of July 6, 2010, BVerfGE 126.

37 Paras $26-30,48$. This 'identity review' was established by the German Court itself in the Lisbon Treaty Decision, BVerfG 123. The argument that OMT could render meaningless the German right to vote for elections to Parliament, violating a democracy principle that is inviolable under German Constitutional Law has been described as 'far-fetched' and 'probably too absurd to discuss', see F. Mayer, (2014) German Law Journal 132, above note 6.

${ }^{38}$ See e.g. para 37. Essentially, whether the act is a 'manifest and structurally significant transgression' for the purposes of ultra vires depends not upon its effects in the EU legal order but on the constitutional identity of Germany. According to Garditz, 'the individualization of the democratic process via the vehicle of the right to vote - the identity control standard - and the concept of ultra vires control just do not match'. See Klaus Garditz, 'Beyond Symbolism: Towards a Constitutional Actio Popularis in EU affairs? A Commentary on the OMT Decision of the Federal Constitutional Court' (2014) German Law Journal 189 .

39 This follows the ESM (temporary injunctions) decision, 2 BvR 2728/13 ESM/ECB, Judgment of 14 January 2014.

40 Brunner v European Union [1994] 1 CMLR 57 (henceforth 'Maastricht Decision') and 2 BvE 2/08 Treaty of Lisbon, Judgment of 30 June 2009 (henceforth 'Lisbon Decision').
} 
EU law, the ECJ has exclusive competence to rule on the validity of EU acts and it does so on the basis of EU law, 41 including now in accordance with the national identity provision in Article 4 (2) TEU. ${ }^{42}$ On the other hand, it is part of the genius of the German court that it has presented its view on European integration as a forceful synthesis of national and European constitutional values, prodding and probing the European Court to be more receptive to concerns of democracy and fundamental rights. But if making good on its promise in Honeywell that ultra vires review proceed only after the ECJ has been given a chance to issue a ruling might at first sight appear an act of judicial comity, careful scrutiny reveals it is more of a threat than co-operative embrace. It has been described, accurately, as a 'diktat' rather than a question, presenting the ECJ with a catch-22: invalidate the OMT decision, render it ineffective (by adopting the escape route offered to it), or risk constitutional collision with Germany. ${ }^{43}$

To capture the significance of this growing line of jurisprudence emanating from Karlsruhe, the constitutional background to the issues raised by the German Court must first be brought into focus. It has been a refrain in European legal scholarship, from at least as far back as the 1970s, that the German court has put up strong if ultimately untested resistance to the absolute primacy of European law and the authority of the EU and the ECJ, based on concerns first of human rights, ${ }^{44}$ then of democratic legitimacy, ${ }^{45}$ and recently of the more 'juridical' notion of 'constitutional identity'. ${ }^{46}$ Over the years, the court has been much maligned in European legal commentary, but has not been without its defenders or at least those who sought to paint a more nuanced picture of the court's dilemma, faced with a duty to protect a rights-centred domestic constitution with entrenched guarantees of democracy, as well as to promote an 'openness' to European integration written into the Basic Law itself. ${ }^{47}$ There was little doubt that it aired genuine concerns about the legitimacy of the European construct over the course of its rulings, even though it aired them from a German point of view. And therein lies the rub. ${ }^{48}$

\footnotetext{
${ }^{41}$ See Case 314/85 Foto-Frost v Hauptzollamt Lubeck-Ost [1987] ECR 4199.

${ }^{42}$ See the ECJ's decision in Sayn-Wittgenstein, Case 208/09. The meaning of Article 4(2) TEU has yet to be settled. For an argument that it should be considered part of ordinary EU law, to be used in case of balancing national and EU interests when derogating from EU law, rather than in exceptional cases of constitutional conflict, see B. Guastaferro, 'Beyond the Exceptionalism of Constitutional Conflicts: The Ordinary Functions of the Identity Clause' (2012) Yearbook of European Law 263 - 318.

${ }^{43}$ See F. Mayer, above note 6, describing the reference as a 'diktat'. On the catch-22 see Gerner-Beuerle, and Schuster, above note 2.

${ }^{44}$ The so called Solange jurisprudence of the BVerfG, IHT v Einfuhr und Vorratsstelle fur Getreide und Futtermittel [1974] 2 CMLR 540 and Wunsche Handelsgesellschaft \{1987] CMLR 225.

45 'Maastricht decision', above note 40.

46 'Lisbon decision', above note 40.

47 Article 23 GG.

48 As Michelle Everson and Christian Joerges puts it in response to the earlier German Court's judgment on ESM, 'why is budgetary autonomy not understood as a common European constitutional legacy?' in M. Everson and C. Joerges, 'Who is the Guardian for Constitutionalism in Europe after The Financial Crisis?' (2013) LEQS paper no 63/2013, at 17.
} 
In a European Union which consists of states of vastly different size and power - both economically and geopolitically - there are numerous institutional arrangements that are designed to maintain a balance among them. A 'spatial balance' between members is essential to preserve, because it is only (as yet) in the political context of the nation-state that collective decisions on certain socially sensitive issues can legitimately be taken. ${ }^{49}$ The EU's commitment to selfdetermination may not be redeemed through purely majoritarian mechanisms, at least not at the current stage of integration. Europe simply does not 'dispose of a transnational political system that incorporates each citizen's voice equally'. ${ }^{50}$

The protection of national identity and its fundamental political and constitutional structures is now enshrined in the Treaty itself, along with the principle of equality of Member States, in Article 4(2) TEU, a point not lost on the German court. ${ }^{51}$ And it is clear that this principle applies to all states, small and large. But for Karlsruhe, German constitutional identity review under Article 79 (3) GG is fundamentally different, reaching, in its view, 'far beyond' Article 4(2) TEU.

This substantive principle of equality must be understood alongside particular institutional mechanisms designed specifically to protect smaller states by increasing their relative voice in the integration process, such as degressive proportionality of seats in the European Parliament. From a unitary perspective, this can seem odd: after all, the fundamental principle of modern democratic legitimacy is 'one person one vote'. ${ }^{52}$ But in any federal or quasi-federal system where the identity not only of the individual person but of the constituent parts matters and is considered necessary to protect through formal mechanisms, there are two fundamental principles which remain in delicate tension with one another: equality of persons and equality of states..$^{53}$

The principle of member state equality is not therefore merely a formal one in the EU; it is not contiguous with an international law principle of sovereign state equality but is material in nature. There are numerous and diverse mechanisms aimed specifically to prevent the marginalisation of smaller member states and avoid their domination by larger and more powerful states, although these have been seriously eroded and jeopardised since the financial crisis. ${ }^{54}$

\footnotetext{
49 See Dawson and De Witte, above note 31: 'the overrepresentation of smaller Member States in the Union's institutions serves to mitigate transnational majoritarian tendencies in redistributive and socially contentious policy areas, and to allow the citizens of each Member State to autonomously determine the conditions under which their society is structured.'

${ }^{50}$ Dawson and De Witte, ibid.

${ }^{51}$ See para 29. The German court is at pains to distinguish Article 4(2) TEU from its own protection of constitutional identity.

52 This was advanced by the German court in its Lisbon decision as a reason for rejecting the democratic legitimacy of the Union.

${ }^{53}$ For discussion, see C. Lord and J. Pollack, 'Equality according to Karslruhe' (2013) European Journal of Public Policy 190 - 205.

${ }^{54}$ Dawson and De Witte: 'Within the EU, the instruments for the protection of spatial balance are those of the overrepresentation of smaller Member States in voting arrangements, an independent mediator for the initiation of policy proposals, the system of competences that protects against majoritarianism in sensitive areas, and the rigid treaty revision system, that requires consent of all Member States to 'change
} 
The judgments of the German Court reveal a further factor in the constitutional imbalance of integration, which is an acknowledgement of the disparity in what might be termed juridical or 'constitutional' power between nations. This is neglected in the literature, and it is worth pausing to consider why. The assumption is that juridical 'strength' is a feature not of power but of authority, in the sense of de jure rather than de facto authority. 55 In a different vernacular, the court's authority is presumed to exist by virtue of a constituted rather than a constituent power. The German Court - or any other Court for that matter answers the questions submitted to it and adjudicates the disputes brought before it on the basis of a duty to ascertain and apply the law rather than an opportunity to test or flex its muscle. If there is 'one right answer' to a legal dispute, the only power relevant is the intellectual power required to discern it; if this is a 'Herculean' task, it is one whose function is purely intellectual and moral, a combination of fit and justification of existing legal and political practice. ${ }^{56}$ In the language of a distinct but related theoretical framework, the 'forceless force' of the better argument will prevail so long as the right procedures are followed. ${ }^{57}$

Whether the 'integrity' of law is translated into action depends on a political culture and background social order that has internalised a relatively high level of obedience to the law and at least official acceptance of the rules of law-making. ${ }^{58}$ But the rules of law-making are frequently complex and under-determined, and a Court is also a participant in this balance of constitutional powers; in the language of speech act theory its utterances are 'performative', not merely 'constative'. 59 They are not logical or tautologous propositions of law but require recognition in broader constitutional practice, to be taken seriously as exercises of practical as much as theoretical reason. In short, the constitutional effects of a Court's judgment will depend upon the constitutional context in which it is uttered.

This feature is largely concealed in a standing constitutional tradition, where the 'balance of powers', or in classic public law, their 'separation', has already been established over years, perhaps centuries, of conflict and negotiation and attained what appears to be some kind of stable constitutional equilibrium. Juridical

the rules of the game', see above note 31 . They note in detail how this has altered as a result of reforms since the financial crisis.

55 Analytical legal philosophers have struggled to come to terms with the dual aspect of authority, de jure and de facto. For an illustration of the difficulties, see e.g. J. Raz, 'Revisiting the Service Conception of Authority' (2006) 60 Minnesota Law Review 1003.

56 The reference of course is to Dworkin, see Law's Empire (Harvard University Press, 1986). But if Dworkin's theory is at home in elaborating answer to legal questions within a standing liberal constitutional tradition, such as whether a party is liable in tort law for causing psychiatric harm, it appears at sea in dealing with questions of state sovereignty and fiscal responsibility in a supranational Union of states, not least because Hercules is a 'loner'.

57 The reference is to Jürgen Habermas, see e.g. Between Facts and Norms: Contributions to a Discourse Theory of Law and Morality (MIT, 1998).

58 These are akin to the minimal conditions Hart poses for the existence of a legal system. See The Concept of Law (Oxford, Clarendon, 1962).

${ }^{59}$ See J. L. Austin, How to do Things with Words (1962). So for example, its most foundational decisions are often described as exercises in boot-strapping. 
authority thenceforth appears a distinct and even autonomous phenomenon, at least in the abstract analysis of legal scholars, concerned to present a snapshot of the constitutional order, or what has revealingly been called a 'momentary legal system'. ${ }^{60}$

The Herculian reconstruction of institutional 'integrity', moreover, despite its normative ambitions, is in a decisive sense parochial, existing within a polity that however still divided internally - is assumed to be constitutionally stable in its sovereign authority, and in the analytical tradition of normative political theory, generally assumed to be 'closed' in term of its membership. ${ }^{61}$

Even in a well-established polity, inter-institutional tension and the possibility of outright conflict between constitutional powers lurk below the surface and frequently remind us of their presence. ${ }^{62}$ In a dynamic, compound system such as the EU where there is a deeply ambiguous and contested division of political and judicial labour both within and between levels of government and the second order question of 'who decides?' and even 'whose interests count?' is itself up for grabs, judicial assertiveness will be another but significant factor in determining both the content of the law and the legal order that prevails. This explains the significance of the judicial Kompetenz - Kompetenz debate - now put to the test by the German Court in its laced referral to the Court of Justice in OMT. If analytical legal theory is ill equipped to account for judicial and constitutional evolution, it is left floundering in the wake of revolutionary judgments, of the kind that can and have transformed an international into a quasi - constitutional order such as those foundational of the European Union. ${ }^{63}$

After the ECJ had revolutionised our understanding of the European legal order with its doctrines of direct effect and supremacy, the relationship between national and supranational juridical authority was long conceptualised as subject to a tense but ultimately non-catastrophic 'stale-mate' between the Court of Justice and the German Court, reminiscent of the MAD ('mutually assured destruction') logic, preventing either side from detonating its juridical bomb. ${ }^{64}$ Instead of

\footnotetext{
${ }^{60}$ See J. Raz, Concept of Legal System (Oxford, Clarendon, 1980). In the language of constitutional theory, a government's authority, its right to be obeyed (potestas) is conceptually separate from its power, or capacity to compel obedience (potentia). See M. Loughlin, 'Constitutional Pluralism: An Oxymoron?' (2014) International Journal of Constitutional Law. Loughlin elsewhere develops a more dialectical or 'reflexive' account of the relationship between constitutional power and authority. See e.g. M. Loughlin, Foundations of Public Law (Oxford, OUP, 2012).

${ }^{61}$ See e.g. J. Rawls, Law of Peoples (Harvard University Press, 1999).

${ }^{62}$ See e.g. in the recent UK context, Sumption's recent intervention and Sedley's response, in the pages of the London Review of Books. Note that in the Kantian tradition the uncontested sovereignty to decide is central to the maintenance of the civil condition. See e.g. Thomas Pogge 'Kant's Theory of Justice' (1988) Kant-Studien 407, who notes that this is a feature Kant's writing that is deeply problematic: 'abandoning the dogma of absolute sovereignty makes possible not only a genuine separation of powers but also genuine federalism' 433. On the significance of social conflict for constitutional development, see J. A. G. Griffith, 'The Political Constitution' (1979) 42 Modern Law Review 1.

${ }^{63}$ In Kelsen's case, the difficulties of revolution were explored by Harris, 'When and Why does the Grundnorm Change?' (1971) Cambridge Law Journal 103 - 133.

${ }^{64}$ See N. MacCormick, Questioning Sovereignty (OUP, 1999). This metaphor seems now to be replaced with another, of a 'game of chicken', see both Kumm and Mayer, above notes 6 and 7. The metaphorical stakes have apparently been lowered.
} 
conflict, a productive if tense dialogue might even occur between courts. The point of the bomb, of course, is not to use it.

But this idealistic vision of judicial dialogue ignores an important asymmetry, which can be bluntly articulated: the EU includes 27 other member states, each vying for power and authority in the compound constitutional architecture of the EU. None of these is able to exert the influence of the Bundesverfassungsgericht.

If it seems trivial to observe that the authority of the Court of the largest member is likely to be greater than that of any other, ${ }^{65}$ it is far from evident - and would be denied by the prevailing legal normativism - that its authority should be greater by virtue of this fact alone. The Court of course speaks 'in the name of the people' and this 'people' happens to be more numerous than any other in the Union.

If its justifications need only be rendered to 'the German people' on the basis of the constitution spoken in their name, to what extent can it properly pronounce on the legality of EU acts, such as the OMT? According to EU law, the answer is clear: it cannot. Only the ECJ is competent to interpret the Treaty and judge the validity of acts of the EU, albeit within the parameters and exceptions established by virtue of its own jurisprudence. ${ }^{66}$ But the leverage of the German Court vis-àvis its supranational counterpart here is immense, as evidenced by the attention given to its previous jurisprudence. Influence is not the same as authority, but is in close symbiotic relation with it. The realm of the normative, it seems, is far from impervious to facts about power and popularity.

This leverage also surpasses a straightforward realpolitikal calculation of German hegemony. The reason for the German court's extraordinary and elevated authority in the constitutional landscape of Europe is more complex; it is in significant part a function of its authority in the domestic constitutional structure of the Federal Republic of Germany and its ethos of what is often, but misleadingly, termed 'militant democracy'. ${ }^{67}$ Better understood as 'constrained' democracy, or 'constitutional patriotism', the constitutional structure of the Federal Republic places enormous authority in the hands of its Constitutional Court and the Basic Law it is tasked with guarding and upholding. ${ }^{68}$ It does so ostensibly in order to defend the liberal democratic order, even, if necessary, against its own temporary democratic majorities and the government of the day.

\footnotetext{
65 According to Everson and Joerges, 'This court supervises the economically most powerful Member State; nowhere else would a judgment have such far-reaching effect', above note 48, at 16 . See too Weiler's editorial on the Lisbon decision, above note 4, noting Karlsruhe's unique prestige.

66 In particular the CILFIT criteria, see C 283/81 CILFIT v Ministry of Health (1982) ECR 341. According to Mayer, 'the ultra vires doctrine of the German Constitutional Court is not only incompatible with Germany's obligations under EU law [...], it is also in contradiction with established principles of Public International Law and of the constitutional law of federal entities', (2014) above note 6, 117.

67 The term originates with Karl Loewenstein, 'Militant Democracy and Fundamental Rights', Parts I and II (1937) American Political Science Review, 638 - 658 and 417 - 432.

${ }^{68}$ For an account of how this fits in the historical pattern of $20^{\text {th }}$ century democratic thought, see J-W. Müller, Contesting Democracy (Princeton University Press, 2012).
} 
In the post-war settlement, strong constitutional courts - as part of a package of counter-majoritarian institutions - were considered necessary in order to constrain democratic majorities, to avoid backsliding into the authoritarianism that characterised European politics in the first half of the $20^{\text {th }}$ century ${ }^{69} \mathrm{It}$ is therefore deeply ironic that in a constitutional and political culture so sceptical of democracy, and so afraid of 'the people', ${ }^{70}$ restraints on European integration are now formulated in the name of democracy and in OMT judgment itself, 'democratic discourse'. ${ }^{71}$ Rules of the game that were entrenched to avoid a return to dictatorship both constrain and empower the German hegemon in the world of European constitutional politics, as well as provide a missing channel for Germans to voice their Euro-scepticism. ${ }^{72}$

Although devaluing and weakening parliamentarism internally, the effect of strong independent, counter-majoritarian institutions such as constitutional courts can be, paradoxically, to strengthen the governmental apparatus of the state in its external relations. To take certain choices off the table of democratic contestation - albeit 'in the name of democracy' itself - might strengthen the hand of the state in negotiating at the supranational level and also, with regard to its national court, in inter-judicial deliberations in the supranational constitutional architecture, which revolve round a preliminary reference procedure that is quasi-federal in form. As Franz Mayer puts it:

The reality of the Euro crisis is that constitutional law arguments replace political arguments, which goes far beyond an attempt to respect the constitutional framework. The Federal government is not entirely innocent in this development, as they do play the "Karlsruhe-card" domestically and in negotiations in Brussels [...] Clearly, some government bureaucrats have no sense of the potential damage to the community of law that comes with this kind of reasoning.

\footnotetext{
${ }^{69}$ On Müller's account, the EU follows the pattern of 'restrained democracy', and fits into its institutional framework; it is a 'mixed regime', but with a similar logic; intended to strengthen the hand of the member states against extremism including, if necessary, against parliamentary extremism of Left or Right. 'Stability' is the key word in this postwar settlement. Muller suspects that the EU may however have recently turned a corner, mutating into something qualitatively different, see Müller, 'Beyond Militant Democracy?' New Left Review (2012) 39 - 47.

${ }^{70}$ For a full account of this fear as it evolves throughout the $20^{\text {th }}$ century, see C. Möllers, We are (afraid) of the People' in M. Loughlin and N. Walker (eds), The Paradox of Constitutionalism (OUP, 2008). On German legalism and its 'structural distrust in the democratic process', see, K. Garditz, 'Beyond Symbolism: Towards a Constitutional Actio Popularis in EU affairs? A Commentary on the OMT Decision of the Federal Constitutional Court' (2014) German Law Journal, 189. Garditz describes it as a 'striking peculiarity' of the German system that it is restructured after World War II on the basis of individual self-determination and fundamental rights.

${ }^{71}$ See para 37.

72 See e.g. J. Bast, 'Don't Act Beyond Your Powers: The Perils and the Pitfalls of the German Constitutional Court's Ultra Vires Review' (2014) German Law Journal 167 - 182. And Garditz, above note 70 , at 200. But note the recent success of Alternative Für Deutschland, which achieved $4.7 \%$ of the vote in the September 2013 elections to the Bundestag, just shy of the 5\% threshold required to enter.
} 
Even if dressed up as such, the concern of the German Court is not to uphold the autonomy of the Bundestag; it is a paternalistic concern for the integrity of the German Basic Law, that Germany must not commit 'democratic suicide' by transferring unchecked power to 'undemocratic' institutions, including those of the EU. ${ }^{73}$ As well as defending its own prerogative, the concern, as most clearly articulated in the Lisbon decision - however misguided - is for the maintenance of German constitutional sovereignty.

But in effect, and as the dissenting judgments noted, the OMT decision empowers the individual complainant through a substantive reading of the 'right to vote', protected in Article 38 of the GG, and ultimately by the Eternity Clause, and it therefore potentially undermines the authority of the Bundestag and the separation of powers between legislature and court. ${ }^{74}$ And from a European perspective, it must be noted that these complainants are not mere individuals; they are German citizens. ${ }^{75}$

\section{THE INTEGRITY OF THE EU LEGAL ORDER?}

The concern of the German Court to protect a domestic rule of law and the national constitutional guarantees it is charged with safeguarding is of course entirely proper. But there is also a transnational rule of law to consider; a European 'community of law', and an order - however relatively immature and contested -which has its own constitutional identity, political logic and normative values. From this European perspective too, there is a concern for the integrity of the order, including legal certainty, political stability and concerns of equality and fairness that arise in the context of any political association - national or otherwise. ${ }^{76}$ If these began in functionalist style, based on rational but relatively primitive concerns for peace and prosperity in the aftermath of World War II, the EU now claims to be founded on democracy, the rule of law, social justice and solidarity. These are values articulated in Article 2 TEU as 'foundational' of

\footnotetext{
73 A concern which is articulated by the Court in para 48: 'Parliament may not cede the power to decide whether and to what degree sovereign powers are to be transferred, and it may not transfer this power to the institutions of the European Union.' This claim is made unconditionally, without any reference to the democratic legitimacy of the European institutions. On the problem of using an Eternity clause designed to prevent descent into dictatorship in the context of European Integration, see C. Schönberger, 'Lisbon in Karlsruhe: Maastricht's Epigones at Sea' (2009) German Law Journal 1201 - 1218.

${ }^{74}$ Cf. dissenting judgments of Lübbe-Wolff and Gerhardt. As Mayer describes the plaintiffs in the OMT case: 'these are political campaigns and add up to an anti-European political struggle. And they are directed against the legitimate political majorities in Parliament that are the result of a legitimate political process', above note 6.

75 For a compelling critique of the Court's granting of standing to individuals to pursue ultra vires in a case such as this, based indirectly on a violation of their right to vote, see Garditz, above note 70, noting that it requires 'the balancing of general interests that are not represented in court-after all, in the case at hand the very foundations of the political measures taken to contain the Euro crisis are affected. Thus, the definition of standing would require a democratically-sensitive, constitutionally-complex, and institutionally-sophisticated act of balancing.' 196.

76 This requires an account of what has been termed 'political constitutionalism'. See e.g. M. Wilkinson, 'Political Constitutionalism and the European Union' (2013) Modern Law Review, 191 - 222
} 
European Union, and are instrumentalised by German scholars to argue for legal action against 'systematic deficiency in the rule of law' elsewhere in Europe, particularly its Southern and Eastern parts. ${ }^{77}$

In isolation, the Court of Justice's juridical armoury can, however, appear immediately suspect in pitting a weakly legitimated European legal order against a much more strongly legitimated domestic order: the European 'constitution without constitutionalism' is an Emperor with threadbare clothes, if not entirely naked. It is a 'legal without a political constitution', a 'constitution without constituent power', or more poetically, 'a constitutional body without a soul'. 78

The need for a uniform body of EU law is frequently stated without argument, so used is the jurist to assuming the lexical priority of legality as a constitutional value; even the conventional value of the bare legality of positive law. Encouraging enforcement through 'the vigilance of individuals' concerned was a justification for the Court of Justice's early jurisprudence of direct effect. ${ }^{79}$ But of course individuals must be vigilant to other concerns, including political and ethical ones, than bare enforcement of the law, however important that might also be. And of course 'even judges are human', and therefore subject to the same moral and prudential concerns (as well as vices, temptations, and delusions of grandeur) as the rest of the population. ${ }^{80}$

Compared to the German Constitutional Court, the ECJ has only the 'uniform application of EU law', backed up with an array of human rights norms (dubiously qualified by Member State 'opt-outs'), unwritten principles of law, and democratically deficient and opaque law-making procedures on its side in the judicial tug-o-war. ${ }^{81}$ The national courts on the other hand have the powerful local legitimacy of traditional, well-established and entrenched constitutional settlements, which represent collective self-determination in its thickest form. Democracy to put it crudely, is relatively strong domestically and weak supranationally. And the EU, however expansive it has become, develops functionally but on the basis of the principle of conferred powers, as the German Court notes (in paragraph 26):

unlike the primacy of application of federal law in a federal state, the precedence of Union law, which is based on national legislation giving effect to it, cannot be comprehensive.

Even though this is not the way the Court of Justice construes the basis of primacy and EU's law domestic effects, there is nothing necessarily doctrinally mistaken with this view of the legal world. But it is misleading in its failure to

\footnotetext{
77 See A. Von Bogdandy, 'Systematic Deficiencies in the Rule of Law' 51 CML Rev (2014) 59 - 96.

${ }^{78}$ For an argument in greater length against these dichotomies see M. Wilkinson, note 76, above.

79 See C- 26/62 V an Gend en Loos.

80 See J. Raz, 'Incorporation by Law' (2004) Legal Theory 1 - 17. Raz, it should be added, focuses only on the normative, moral constraints on the judge.

81 See, recently, e.g. J. H. H. Weiler, Van Gend en Loos: The Individual as Subject and Object and the Dilemma of European Legitimacy’ (2014) International Journal of Constitutional Law 94 - 103.
} 
acknowledge that both national and European constitutional systems are deeply intertwined in the process of integration; there is no zero sum game in terms of the allocation of authority between them. There is for example, no neat division between national and supranational institutions, let alone between legislative, executive and judicial functions in the EU. The European Commission, for example, performs a complex mix of functions and the European Council represents executive power at multiple levels. Neither, of course, are competences neatly divided or conferred powers clear and exhaustively enumerated, not least due to the existence of implied powers exercised under the 'flexibility provision' of Article 352 TFEU. 82

The project of European integration was not designed democratically, or at least not in the way democracy is traditionally conceived in terms of placing ultimate law-making authority in the hands of the people or their elected representatives. ${ }^{83}$ It is not even meant to be democratically responsive in the way that term is usually understood. Any democratic deficit that the EU suffers from is, in large part, a deliberately constructed one. ${ }^{84}$

Consent, of course, is supposed to provide the missing link in the chain of authorisation from Member State constitution to EU Treaty; this is why the German Court can insist on protecting state sovereignty in the context of ultra vires review, with the EU being a creature of law rather than exercising an original, constituent authority of its own. Although consent is at least partially vitiated or conditioned by the Court of Justice's jurisprudence itself, precipitating the mutation of the international legal order into a quasi-constitutional European order of law in its celebrated early case-law, and this has been given a stamp of inter-governmental approval, it lacks the full and explicit force of a constitutional moment. ${ }^{85}$ The early mutation into a quasi-constitutional order must be understood not only alongside the later political evolution of integration, in particular the move to majority voting in the Single European Act but also the later failure of the Constitutional Treaty in 2005.

There may be an additional, fuller normative argument for EU authority waiting in the wings, to the effect that states should be held to the commitments they make to one another: pacta sunt servanda. ${ }^{86}$ This too is usually taken for granted. But then it needs reminding that bare promises raise, on most accounts, only a pro tanto obligation to comply. Commitments that are made by states are

82 Because of the indefinite nature of this provision, the German Court in its Lisbon Decision adds additional procedural safeguards, requiring use of Article 352 TFEU to be ratified by the Bundesrat and Bundestag. On the deeper facets of the competence conundrum in the EU, and a proposal for reform, see S. Garben, 'Confronting the Competence Conundrum: Democratizing the European Union through an Expansion of its Legislative Powers' (2014) Oxford Journal of Legal Studies 1 - 35.

83 As Peter Mair suggests, the Union would not have been created had elites thought that traditional democracy would be able to do the job. See, recently, P. Mair, Ruling the Void (Verso, 2013).

84 Ibid.

${ }^{85}$ Formalised primacy was one of the casualties of the failure of the Constitutional Treaty, along with the symbolic constitutional adornments, flag, anthem etc [...] missing from the Lisbon Treaty proper.

86 Based, according to Weiler, on an impeccable logic, if suspect hermeneutic, above note 11. 
anyway multiple and complex. The additional concern that with $28+1$ arbiters of EU law there would be too much legal uncertainty for the internal market to function properly is no doubt a legitimate one; but it raises hardly more than a defeasible presumption, if that, of the primacy of EU law and authority of the ECJ.

If legal certainty is one value amongst others, these others - not least equity or fairness beyond the written law, prudential concerns of long-term political stability - must not be concealed from view. This is particularly important because legal certainty in EU law privileges not a legal order comprehensively, but predominantly economically, with a logic that contributes to a structural bias in favour of the construction of a liberal economic order, as Fritz Scharpf has powerfully argued. ${ }^{87}$

And of course the question is often not whether the state consented to or promised $\mathrm{x}$ or $\mathrm{y}$, but what $\mathrm{x}$ or $\mathrm{y}$ means; how that should be interpreted and determined in practice. So a key question from a constitutional perspective concerned not only with is who has the interpretive authority to answer this question and how it should be answered, rather than only what answer can be determined in the mind of a Herculean judge or scholar.

The structure of the preliminary reference procedure in any case is such that it depends upon compound judicial authority rather than strict judicial hierarchy. The inclusion of principles such as Article 4(2) TEU in the Treaty itself has attempted to internalise the subjection of authority to principles of equal national collective self-determination. The German Court construes this idiosyncratically, in divorcing its own doctrine from the more nuanced and holistic perspective offered in Article 4(2). ${ }^{88}$ Core German constitutional identity is exclusive and nonnegotiable, ${ }^{89}$ not only immune to balancing of any sort against other legal interests but also exclusively for the federal constitutional court to interpret.

But genuine co-operation is a two-way street. Although the German court does speak of maintaining its 'friendliness' towards EU law, this sleight of hand understates the point: the German court is also under a duty of loyal co-operation, the principle of 'sincere co-operation' laid down in Article 4(3) TEU. This requires the Court to consider its responsibility not in isolation but as both a national and a European court, and one whose judgements reverberate throughout the Union, and even beyond. ${ }^{90}$

As Fritz Scharpf has argued in response to its earlier Lisbon decision, Karlsruhe's jurisprudence 'appears fundamentally flawed because the court has

\footnotetext{
${ }^{87}$ See F. Scharpf, 'The Double Asymmetry of European Integration: Or Why the EU Cannot be a Social Market Economy' (2012) MPIfG Working Paper 09/12.

88 Para 29.

89 ' $\mathrm{T}]$ dentity review is not to be assessed according to Union law but exclusively according to German Constitutional Law', according to the German Court, para 103. See also para 29.

${ }_{90}$ As Mayer puts it: 'apparently there is not much room for solidarity beyond the borders of the nationstate in the German Constitutional Court's worldview. Some would even detect a lack of constitutional empathy here, considering the fact that concepts the German Constitutional Court invokes quite naturally such as self-determination, budgetary autonomy, etc., are not available to other Member States anymore [...]' above note $6,143$.
} 
failed to consider its generalized implications in the light of the Kantian categorical imperative'. ${ }^{91}$ The Constitution, on this account, is 'founded upon a universal rather than particular principle of democratic sovereignty'. ${ }^{92}$ Karlsruhe fails, in other words, a version of the golden rule of ethics; constitutional authority must be subject to the moral law.

Some sort of balance between the values of European community on the one hand and of national autonomy on the other must be sought by the constitutionally responsible court in the EU, as Scharpf argues. This is a far from easy task. 'A normatively and pragmatically acceptable balance' cannot be achieved by national high courts declaring 'unilateral opt-outs from European law in procedures in which the interests of other EU member states and the concerns of the Union have no voice at all'. ${ }^{93}$ As Scharpf continues:

The authority claimed by the German court could of course not be denied to the courts in all member states. And while these would surely be equally sensitive to the specific and diverse concerns of national autonomy and identity, there is no reason to expect that their understandings of the "Europe-friendliness" of their national constitutions would converge, or that they would all assign the same relative weights to the European concerns at stake. The overall result might be a chaotic form of differentiated integration through an accumulation and perhaps escalation of unilateral national optouts. ${ }^{94}$

The role of the German court has changed since the Basic Law was enacted; it must internalise a principle of co-operation, not only with the ECJ but also with the other Union institutions as well as the political, social, and economic relations of 27 other member states as these are constructed through the Union's laws, principles and institutions. It may seem far removed from the technicalities of the OMT, but consider, for example, the citizenship law of the Union, inserted into the Maastricht Treaty and generously interpreted by the European Court of Justice in its case law. ${ }^{95}$ The Court of Justice has long proclaimed a duty of 'financial

\footnotetext{
91 See F. Scharpf, above note 87. And Mayer, if all other supreme or national courts in the EU took the same stance, the unity of EU law and the authority of the ECJ would be destroyed', above note 6, at 133 .

92 M. Everson, 'An Exercise in Legal Honesty: Re-Writing the Court of Justice and the Bundesverfassungsgericht' (2014) Institute For Advanced Studies Vienna, Political Science Series. See also M. Kumm, above note 7, asking rhetorically: 'Given that the court is interpreting the meaning of the universal idea of democratic statehood, a concept that is part of the shared constitutional heritage of Member States and not an idiosyncratic national commitment, why does it not engage in any serious way the jurisprudence of other Member States courts on this point?' at 211.

93 Scharpf, above note 87.

94 Scharpf, ibid. Also Mayer, 'establishing national constitutional identity as a limit of EU law unilaterally is extremely dangerous for legal unity in the EU and open to abuse', above note 6, at 133 .

95 See e.g. See e.g. C- 184/00 Grzelczylk [2001] ECR I-6193. For a thorough examination of the citizenship case-law see F. Wollenschlager 'A New Fundamental Freedom Beyond Market Integration' (2011) 17 European Law Journal 1. In C- 34/09 Ruiz Zambrano, the Court of Justice boldly extends the effects of EU citizenship to purely internal situations, crossing, according to a recent comment, a 'conceptual threshold
} 
solidarity' between Member States of the Union, even if restrictively interpreted. The Treaty itself stipulates obligations of co-operation as well as competition across and within the Union, including duties of solidarity and social justice. ${ }^{96}$

It would be misleading therefore to point to the constraints of the legal materials, to the extent that the sources of law are frequently indeterminate in meaning and, by now in the EU, virtually unlimited in scope. If moral considerations can figure in its decision-making processes, why not political, prudential ones, based on the stability of the political or economic order on which the integrity of the positive law depends? The German Constitutional Court is more than a guardian of the law; it is the guardian of the Constitution. ${ }^{97}$ It is also holding itself out as the Guardian of the European Constitution, or at least its chief lieutenant, protecting it against the illegitimate incursions of a powerful (and also counter-majoritarian) supranational institution, the European Central Bank.

But by presenting itself as a Guardian of the European constitution it has to take into account values beyond those it traditionally protects as a national court. To fail to do so carries the risk of constitutional hazard, the risk that the European construct will be conditioned and even determined by the constitutional power of a domestic court expressing domestic concerns. The risk then is that the Federal Republic of Germany will, in its relations with other Member States of the European Union, end up contracting 'with slaves'. ${ }^{98}$ This would, one supposes, mean the end of the project of European integration or, at the very least, mean it has turned into something qualitatively different from its founding mission.

\section{ECONOMIC MESSIANISM AND ITS DISCONTENTS}

Although Karlsruhe rejects such concerns, including any concerns for the 'composition' of the Euro currency area, which it deems to be exclusively of 'economic policy' and therefore for the Member States and not the EU to determine, 'Grexit' would have had a profound impact on stability of the Euro and on the EU as a whole, and therefore of course on Germany too. ${ }^{99}$ OMT clearly fits into a package of rescue measures designed to prevent 'Grexit' - or any other Member State exit - by making the Euro a safer bet for the financial markets. But at what cost to the integrity and constitutional identity of the EU and its Member States?

- even by the generous standards of the flexible ECJ case-law' see K. Hailbronner and D. Thym, 'Case Law' (2011) 48 Common Market Law Review 1253.

96 Ibid.

${ }^{97}$ It is ironic of course too that the German constitution is not really a 'Constitution' but merely a Basic Law. Even upon reunification there was no exercise of the constituent power, as had been intended. For discussion, see C. Möllers, above note 70.

${ }^{98}$ See M. Everson, above note 92 . This raises, as Mayer puts it, the German interest paradox, see above note 6 .

${ }^{99}$ Para 72. 
If Scharpf's moralisation of constitutional hazard might be impeccable as a matter of ethics, reaction and response to the financial crisis in Europe suggests that the integrity of the law as a freestanding and systemic normative order is fictional, depending for its sustenance on a concrete political and economic order behind it. It suggests that 'norm follows normality'. 100 And in the absence of political and economic normality - and to restore normality - normative orders will be by-passed or suspended if necessary. ${ }^{101}$ Integrity is subsumed by the will to survive and, in an asymmetric federation such as the EU, the 'reluctant hegemon' along with the technocratic powers at the centre, will call the shots. ${ }^{102}$

In this new configuration, democratic authority is replaced by a combination of executive powers and market rationality, defended by the perceived necessity of acting swiftly and bypassing public debate. ${ }^{103}$ The decision of the ECB to pursue OMT is an example now of how a 'non-political' institution will take up the slack, suspending normal procedures and using extraordinary ones, offering itself in effect as a lender of last resort in an attempt to restore and maintain normality qua currency stability and financial stability more generally, serving the second order telos of survival of the euro as a whole. ${ }^{104}$

The logic of OMT is to protect a European raison d'etat, albeit based not on solidarity, identity or mutual recognition but on economic-systemic stability. ${ }^{105}$ This prefigures the emergence of 'militant economics' in place of the narrative of 'militant democracy': to protect markets it might be necessary to suspend them. ${ }^{106}$

100 On the relation between norm, normality, and abnormality, see H. Lindahl Fault Lines of Globalization (OUP, 2013)

101 The OMT judgment therefore raises an important question mark over whether liberal constitutional logic is simply too cumbersome to deal with the accelerated decision-making apparently required in conditions of late capitalism. The pace of economic, political and institutional change since the financial crisis has been breath-taking; bypassing many of the political and legal safeguards that have been constructed in the acquis communautaire over many years of 'integration-through-law'. The relationship between capitalism and the rule of law may be a tenser one than both liberal legal scholars and some of their more critical opponents have imagined. See e.g. W. Scheuerman, 'Democratic Experimentalism or Capitalist Synchronisation' (2004) Canadian Journal of Law and Jurisprudence.

102 For a curiously neo-Schmittian position, identifying the 'enemy within' the neo-liberal constitutionalism as those 'bad Europeans' who disregarded the stability criteria, see U. di Fabio, 'Karlsruhe Makes a Referral' (2014) GLJ, 110. For Di Fabio, oddly, the crisis was caused not by financial problems accumulated over years of ne0-liberal excesses (as even many of its architects concede) but 'massive violations of the law', without explaining the chain of causation. He also appears to query the independence of the ECJ because it has a Greek president, ibid.

103 See M. Wilkinson, 'The Specter of Authoritarian Liberalism: Reflections on the Constitutional Crisis of the European Union' (2013) German Law Journal 527 - 560, for an outline of the features, and dangers, of 'authoritarian liberalism'. And, outlining the rise in discretionary executive power, see J. White, 'Emergency Europe' (2014, forthcoming) Political Studies. .

104 See Tuori and Tuori, above note 18.

105 Similar to ESM, see D. Chalmers, 'European Restatements of Sovereignty' (2013) LSE Working Paper Series: 'The ESM's mission is to safeguard euro area and national financial stability. The associative ties established by it are not concerned with securing mutual recognition of citizens or of realising common purposes. They are to secure order and the survival of the system: a European raison d'état in which the latter becomes not simply a value in itself but possibly the highest value. Other forms of associative tie are consequently downgraded relative to this mission.'

106 J. W. Müller, 'Beyond Militant Democracy?' New Left Review (2012) 39 - 47. 
Unconventional monetary policy such as OMT is deployed in order to maintain the conditions for the market economy to function normally, by reducing 'irrationally' high spreads in the periphery.

The sovereign Machiavellian prince is now partly constituted by a depersonalised, collective 'prince of Money'. But this is a prince without a principality, a 'currency without a state'. ${ }^{107}$ The ECB, as institutional representative of this principality, is not even in a comparable position to the Bundesbank; it is disembedded, lacking political, social, and cultural support, having to rely on a strictly delimited constitutional mandate and pure output legitimacy. ${ }^{108}$

So if a Schmittian lens places the constitutional crisis faced in Europe in a starker light than the prevailing normativism, ${ }^{109}$ confronting the apparent priority of the existential ('the Euro must be saved at all cost!') over the normative (the constitutional separation of powers) and the exception over the rule, the exception now - the moment of emergency - is created by the perception of having to restore the confidence of the financial markets rather than establish the political unity of friend versus enemy.

As Wolfgang Streeck neatly puts it, gaining the confidence of the Markvolkt rather than the Statsvolk is essential for the neo-liberal projects of political and economic reform. ${ }^{110}$ Financial markets will not tolerate uncertainty, and have little interest in democracy, preferring decision to deliberation, and executive action to legislative discussion. It also seems that, for the time being at least, they favour austerity and internal devaluation as methods of facilitating further modes of capital 'accumulation by dispossession'; amounting to what has been called 'planned laissez faire'. 111

The implications of new forms of 'authoritarian liberalism' in this reconfiguration are clear: 'integration through law' has been replaced with 'integration through fear', 112 occasioning a rise in 'ersatz law' and managerial decision-making, diktats and discretionary power, extraordinary backroom deals and emergency executive action. ${ }^{113}$ These are justified, if at all, in the name of economic and political necessity (TINA), maintain a rhetoric of economic liberalism whilst interfering incessantly into democratic practice.

\footnotetext{
${ }^{107}$ See W. Bonefeld, 'Neo-Liberal Europe and the Transformation of Democracy: on the State of Money and Law' in P. Nousious, H. Overbeek and A. Tsolakis (eds) Globalisation and European Integration (Routledge, 2012). See also Aglietta, above note 10, at 20.

108 See Tuori and Tuori, above note 19, at 29. See also, G. Majone, 'Rethinking European Integration After the Debt Crisis' European Institute, UCL, Working Paper 3/2012: 'The ECB is political and socially disembedded because it cannot interact with a fully-fledged European government, or even with a European finance minister, not to say an inexistent European public opinion', 14.

${ }^{109}$ See e.g. M. Everson and C. Joerges, note 48 above, and C. Joerges, 'Europe's Economic Constitution in Crisis and the Emergence of a New Constitutional Constellation', Zentra Working Paper, 06/2012, which can be found here: http://papers.ssrn.com/sol3/papers.cfm?abstract id=2179595. Others downplay the exceptional nature of post-crisis response; see e.g. Tuori and Tuori, above note 18.

110 Streeck, Buying Time: The Delayed Crisis of Democratic Capitalism (Verso, 2014) 152.

111 See e.g. D. Harvey, The New Imperialism (OUP, 2003), Streeck, above note 110.

112 See J. H. H. Weiler, 'Editorial: Integration Through Fear' (2012) 23:1 European Journal of International Law $1-5$.

113 For a comprehensive picture, see Menendez, above note 18. See also J. White, above note 103. For an account of authoritarian liberalism, see Wilkinson, note 103 above.
} 
If OMT was considered necessary to preserve an economic order, and to restore financial stability, is whoever is capable of acting, - in other words, the $\mathrm{ECB}$ - now 'sovereign'? Does the ECB have the capacity to decide on the exception in this transformation of constitutionalism in the process of European integration? 114

The answer for Karlsruhe is an emphatic 'no'. The argument that resonated with the German Court is clear: 'the ECB does not have a mandate to defend the Euro by any means'. ${ }^{115}$ It has no mandate to step in as the absent European sovereign, to express the European raison d'etat by rescuing its currency. Any implicit claim to sovereignty by the ECB - to decide on the exception - is dismissed by the German Court, on the basis that it violates the constitutional identity of the state most central to the prospects of European integration. So much for the 'Draghi'!116

Unlike ESM, which in the Advocate General Kokott's view in Pringle represents a legitimate expression of Member State sovereignty, ${ }^{117}$ OMT has not been designed or even explicitly approved by the collective 'Masters of the Treaties' of the European Union. OMT, in other words, is a threat to state sovereignty in a manner that ESM was not. It represents a fusion not of state power and capital but of technocracy and capital, and is therefore a threat to the Westphalian constitutional order as defended by the German Constitutional Court.

Shouldn't the German Court therefore be celebrated for putting up a lastditch defence of juridical logic and the rule of law against the technocraticeconomic dictates of the ECB? Shouldn't Karlsruhe - for all its methodological nationalism and ethical one-dimensionality - be feted for dutifully reasserting the Westphalian Rechtsstaat against the functional logic of monetary union and a belief in Economic Messianism?

It is not that straightforward. EMU was structured so that Member States would maintain fiscal discipline because subject to the logic of the market; their ability to service their existing debts through borrowing would be determined by economic rationality. OMT steps in, according to the ECB, to prevent or counteract the irrationality that infected the financial markets in the wake of the financial crisis. The German court rejects this view, but not because it rejects market logic as such. On the contrary, its view of the rationality of the interest rate spreads on ailing Member States mirrors that of the Bundesbank:

114 Everson and Joerges, above note 48, suggesting that recourse to Carl Schmitt is anything but farfetched in the current crisis context, at 23.

115 Para 5.

116 This is the expression used by Jurgen Bast, to describe a fictional currency supported by Draghi's promise to do 'whatever it takes' to save the Euro. See above, note 72.

117 Opinion of A-G Kokott in Case C-370/12 Pringle v Government of Ireland, Ireland and the Attorney General, para 138. 
according to the European Central Bank, these spreads are partly based on fear - declared to be irrational - of investors of a reversibility of the Euro. However, according to the convincing expertise of the Bundesbank, such interest rate spreads only reflect the scepticism of market participants that individual Member States will show sufficient budgetary discipline to stay permanently solvent. ${ }^{118}$

Whereas for the European Central Bank, OMT legitimately remedies an 'irrational' market fear of reversibility of the Euro, for Karlsruhe, it violates a politicaleconomic logic of fiscal discipline, dis-incentivising sound national budgetary policy. But this in itself is based exclusively on the ordo-liberal logic of an open market economy with free competition, which although an important part, is not the whole of the European constitutional construct.

This logic becomes magnified when noting that an important concern for the German court is that OMT potentially bypasses the conditionalities imposed by ESM, which were intended to maintain fiscal discipline and therefore minimise moral hazard where financial assistance was granted. ${ }^{119}$ From this perspective, the case turns on a technical disagreement between counter-majoritarian institutions on the economic rationality of spreads on sovereign bonds. ${ }^{120}$ It represents not a check on the exercise of 'majoritarian' power, but in fact a clash between a number of counter-majoritarian institutions: Karlsruhe, the Bundesbank, the European Central Bank and the European Court of Justice. It represents a clash of technocratic, scientific opinion as much as institutional power and authority. In an era dominated by an increasing deference to market logic or 'Economic Messianism', the German Court is hardly bucking the trend.

Who, then, is the Messiah? According to Karlsruhe, it is 'the scientifically documented character of monetary policy' that justifies Central Bank independence, ${ }^{121}$ but the Court is keen to add that it finds more 'convincing' the expertise of the Bundesbank than the ECB! ${ }^{122}$ The vote of confidence in Central Bank independence is not, in other words, extended to any central bank in general; and it is not extended to the ECB in particular. It is the Bundesbank that exercises ultimate (theoretical) authority. Defending this, rather than the autonomy of the Bundestag, is Karlsruhe's core concern.

\footnotetext{
118 Para 71. The Court concludes, oddly perhaps, that 'the distinction between rational and irrational' is meaningless in a market-based pricing context. Para 98.

119 Para 79. See section 1 above.

120 As the German court puts it on the question of the democratic legitimacy of central bank independence, reiterating its Lisbon decision: 'this modification of the principle of democracy in order to protect the confidence placed in the value of a currency is justifiable because it takes into account of the special feature of monetary policy - tried and tested in the German legal order, and also by the scientific community - that an independent central bank is more likely to safeguard the monetary value $[\ldots]$ than state bodies [...] which need to rely on short-term approval by political forces'. Para 32, reiterated in para 59 .

121 para 59

122 para 71.
} 
But these supposedly 'scientific' opinions remain subject to a deeper political logic: the will to succeed, or at least to survive. ${ }^{123}$ The rationality of interest rate spreads is a case where economic logic reaches its limit, not least because of the well-documented market failures in this domain. ${ }^{124}$ Rationality in this case depends upon the credibility of the belief in the political will to support a currency, the ECB's assertion - and Karlsruhe's rebuttal, based on the advice of its preferred consultant on matters of economic rationality, the Bundesbank - that the yield on sovereign bonds of ailing states became irrationally low due to the failure of the financial markets to take into account the irreversibility of the Euro depends on a political logic of (in)action. ${ }^{125}$

Although the credibility of European unity is lacking in the absence of the organic bonds of a 'demos' or political community to undergird it, its future is still ultimately contingent on political action nonetheless, even with the obstacles of the consensus required for Treaty amendment or the more radical constitutional constraints imposed by domestic constituencies. Constitutions, after all, can always be amended. The constituent power has not been extinguished.

The Euro, although 'a currency without a state', has been backed by significant political and even state-like commitments. That the Euro must be saved at all costs was an imperative suggested not only by Mario Draghi, the technocrat, but Angela Merkel, the statesman. Political elites, particularly in Germany, have staked their legacy on its success. Although that success has now been threatened by the juristic authority of a domestic court, the viability of the project remains a question of politics. And yet if credible political action is to come from anywhere at all, it can at present only come from where it is least likely to come, the Member States themselves; there is little room for political democracy at the pan-European level. This impasse reinforces a constitutional disequilibrium whose effects are now being acutely felt across Europe.

\section{CONSTITUTIONAL DISEQUILIBRIUM IN ‘A CURRENCY WITHOUT A STATE'}

The erosion of belief in a European political-democratic logic reflects a deeper disequilibrium in the process of European integration. This forces a revision of the dominant narrative, which had suggested, in one particularly influential account, a

\footnotetext{
123 The German Court does not adopt the 'second-order telos' of financial stability, suggested by the ECJ in Pringle, one Tuori and Tuori's interpretation, above note 18.

124 See Gerner-Beuerle and Schuster, above note 2.

125 Arguably it is a political will that the markets must earlier have considered reasonably robust (to the extent the prospect of crisis was considered at all), otherwise why, in the 'good times', was Greece, for example, able to borrow at the relatively low interest rates? The limits of market logic to maintain national fiscal discipline were understood; they explain the (admittedly soft) attempts at co-ordinating fiscal responsibility and economic management through the stability and growth pact.
} 
fortuitous duality of normative supranationalism and political intergovernmentalism. ${ }^{126}$ Accordingly, the EU functioned as a quasi-federal polity, with an idiosyncratic but productive split between normative authority, which became strongly supranationalised through the ECJ's jurisprudence, and political power, which remained predominantly with the component national units of the Member States.

If this split remained functional and in equilibrium until the Single European Act in 1986, by the time of the Maastricht Treaty in 1992 it was becoming increasingly dysfunctional, leading to a 'decade of doubt' that culminated with the failed Constitutional experiment and subsequent 'reform' Treaty of Lisbon that came into force in 2009. And if the nineties was a decade of doubt, with increasing domestic contestation of the project of integration, the noughties was a decade first of disappointment, and then of disaster, laying the ground for a slow constitutional mutation towards an unknown but rather bleak looking future.

Maastricht is widely considered to represent the turning point in the path of integration. ${ }^{127}$ Geo-political shifts of seismic proportions had occurred, with the fall of the Berlin Wall opening Europe to the East and the reunification of the Federal Republic of Germany returning 'the German question' to the centre stage of European politics. The precise role of EMU in these geo-political reconfigurations of global proportions is disputed. ${ }^{128}$ What is clear is that the Maastricht Treaty sowed the seeds for the recent economic debacle, because of its quasi-constitutional commitment to a de-politicised monetary policy based exclusively on price stability, independence of a European Central Bank without orthodox monetary tools and the absence of any supranational economic policy capable of dealing with uneven development, socio-economic heterogeneity and exogenous fiscal shocks. Maastricht also ushers in a new understanding of integration in terms of what was euphemistically referred to as 'variable geometry', the differentiation - initially thought merely temporary - of Europe through optins and opt-outs, the UK and Denmark's opt-out from the third-stage of EMU being the case in point.

The post-Maastricht era also signalled a departure from the previous functional logic that political integration would follow economic integration, and that politicisation would then force elites to engage mass publics in European matters. EMU, on the contrary, entrenched de-politicisation of a key aspect of macro-economic policy, removing an important power from the political pillars of the Member States but without reconstructing it at the supranational level. If the

\footnotetext{
${ }^{126}$ For the classic statement of this duality and its evolution in the early years of integration, see J. H. H. Weiler, 'The Transformation of Europe' (1992) Yale Law Journal 2403 - 2483. See too J. H. H. Weiler, explaining the early equilibrium and balance achieved through this duality, 'The Community System: The Dual Character of Supranationalism' (1981) Yearbook of European Law 267 - 306.

127 Hooghe and Marks identified the year 1991 as the end of the phase of 'permissive consensus' and the beginning of 'constraining dissensus' on integration, from quiescent public opinion to increasingly fractious political debates and partisan conflicts. See G. Marks and L. Hooghe, 'A Postfunctionalist Theory of European Integration: From Permissive Consensus to Constraining Dissensus' (2009) 39 British Journal of Political Science $1-23$ at 5.

128 See Menendez, above note 18, for a compelling account.
} 
construction of EMU was a 'constitutional monstrosity' from the outset, as many now seem to think, it was of course a monster the German Court was integral in constitutionalising in its very own Maastricht decision, twenty years earlier. ${ }^{129}$

A fuller account of the duality between supranational norm and national political power must therefore move beyond any formalistic picture of a balanced bifurcation of legal and political pillars ('dual supranationalism'). It must capture their dysfunctional inter-relation: the substantive constitutional effects of an economic supranationalism (or 'economic constitution') spearheaded by the symbolic unity of a single currency on the one hand and an (increasingly) asymmetric political inter-governmentalism, captured in the currently voguish label, a 'German Europe' on the other. ${ }^{130}$

In the absence of a strong and democratic sovereign European state to back the currency and its economic order, the political slack is taken up by a combination of bureaucratic-economic power, personified by the 'Troika', and political power, exercised by the Member States, or rather the political and economically robust most among them, depending on their willingness and capacity to resume centre stage in order to attenuate the crisis.

And yet even at the Member State level, at least outside the periphery, there is rarely a strong reassertion of the primacy of 'the Political', at least not overtly; it is the 'Schwabian household', we are told, that should be the economic model for fiscal austerity in Europe. It is tighter budgetary discipline that will restore economic equilibrium to the transnational Grossraum. 131

There is no single indisputable Guardian of a European 'Constitution' to reassert its core identity in times of conflict and crisis but only numerous and competing contenders: the Commission, the ECJ, national Courts, national parliaments, the ECB, the Bundesbank, and the Franco-German political axis, or at least one half of it, - no doubt others could be imagined. The unelected and technocratic European Commission, it must be remembered, is, formally, the 'guardian' of the European Treaties. Transnational democracy or solidarity is hardly to be seen, at least outside the informal protests of social movements and their attempts to generate political alternatives. ${ }^{132}$ But then, outside the fringes of subterranean politics, and the impotent rage of reactionary nationalisms, what pressure can democracy exert on this spectacularly fragmented political constitution?

\footnotetext{
${ }^{129}$ Everson and Joerges, above note 48.

${ }^{130}$ See Beck, above note 35.

131 This rhetoric reflects the substitution of the social for the political that Arendt laments, tracing it back historically to the philosopher of bourgeoisie individualism, Thomas Hobbes. See H. Arendt, Chapter 2 of the Origins of Totalitarianism (New York, Harcourt, 1958).

132 See Mary Kaldor, Sabine Selchow, Sean Deel \& Tamsin Murray-Leach, The Bubbling up of Subterranean Politics in Europe (London School of Economics, Civil Society and Human Security Research Unit, 2012), available at www.subterraneanpolitics.eu. The potential of Podemos in Spain, which has seen an extraordinary rise in popularity in a short time, and Syriza in Greece, to generate political alternatives remains to be seen.
} 
The difficulty in answering this question exposes deeper fault-lines in the logic of late democratic capitalism. One logic - if not always reality - of economic integration is geared towards creating and maintaining the conditions for supranational capital and markets to flourish: this prizes efficiency, as the ordoliberals believed and as the German Court demands. ${ }^{133}$ It distrusts democracy. ${ }^{134}$ But in times of financial crisis, it also demands huge injections of liquidity, the apparatus of political rule, and increasing resort to modes of bureaucratic control and central bank governmentality.

The creation of a 'predictable social and administrative order' and conditions 'congenial to accumulation' appear paramount as an economic imperative of market capitalism. 135 This follows a 'scientific' or technocratic logic rather than a 'political' logic of unity, a judicial logic of justice or social logic of solidarity. ${ }^{136}$ But the degree of supervision necessary for a functional re-ordering of capital accumulation - whether through economic 'growth' or 'austerity' -calls for a supranational state and associated bureaucratic-economic apparatus. In the EU, the extra-economic coercion required to maintain an order congenial to market economics and capital accumulation is not a military project - as it has appeared in imperial form at a global level - but neither is it one backed by a democratic political community. ${ }^{137}$ It is a legal and constitutional project, although backed increasingly by police powers of control and surveillance which function outside the usual procedural guarantees and safeguards of the social-democratic Rechtsstaat. ${ }^{138}$

Moving beyond the European Union, a global state apparatus might seem prerequisite in order to maintain the conditions of unhindered capital accumulation. But it is not only that as things stand this is inconceivable; it is also that capital benefits from competition and asymmetrical power relations between nations, with increased geographical labour and capital mobility and imperatives of deregulatory tax competition, as well as more straight forward tax avoidance, from the 'Treasure Islands' of the UK to the 'Fairyland of Luxembourg'. ${ }^{139}$ In this

\footnotetext{
133 On the link between the micro-economic and the macro-economic layers of the European Economic Constitution, see Tuori and Tuori, above note 18, at e.g. 36.

134 On the tensions between capitalism and democracy, see W. Streeck, 'The Crises of Democratic Capitalism' (2012) New Left Review. See also W. Streeck, Buying Time (2014) and Politics in an Age of Austerity (2012). This disequilibrium in the EU is explored in M. Wilkinson, 'Politicising Europe's Justice Deficit: Some Preliminaries' (2014) LSE Working Paper (forthcoming in D. Kochenov, G. de Burca and W. Williams (eds) Europe's Justice Deficit, Hart).

${ }^{135}$ E. Wood, 'Logics of Power: A Conversion with David Harvey' (2006) Historical Materialism, 24.

${ }^{136}$ Independence of the central bank itself is a good example of this partial dominance of economic logic. In the words of the German court, although such independence undoubtedly restricts democracy, it is compatible with democratic principle because it takes the tested and scientifically documented special character of monetary policy into account'. Para 59.

137 In 2007, Jose Manuel Barroso characterised the EU as a 'non-imperial Empire'. See http://euobserver.com/institutional/24458.

138 See, e.g., Menendez, above note 18.

139 On the UK see Nicholas Shaxson, Treasure Islands (2011) and on Luxembourg, 'rubber-stamping' tax avoidance on an 'industrial scale':

http://www.theguardian.com/business/2014/nov/05/-sp-luxembourg-tax-files-tax-avoidance-industrialscale.
} 
second inflection, the political logic of capitalism reinforces the 'fragmentation of the global system into territorial entities' rather than its political or constitutional up-scaling through projects of imperial command and control. ${ }^{140}$

Fragmentation also puts downward pressure on workers to compete using the neo-liberal tools of labour-market wage discipline and job flexibility. This is exacerbated for those in the Eurozone, and now even constitutionalised through the strict conditionality attached to financial assistance justified on the basis of avoiding moral hazard: in the absence of currency devaluation as a tool with which to restore competitiveness, internal devaluation - spending cuts and reducing labour costs - is pressed as the only way of restoring economic health.

In the late stages of democratic capitalism, European integration gets pulled in different directions that are not always aligned and that frequently create friction; upwards towards the supranational union and its logic of economic integration, inwards towards the economically powerful states and in particular the (reluctant) political hegemon at its centre and outwards in the competition between national capitals.

There are, it seems, genuine contradictions in the logic of late capitalism, which are transforming the nature of the constitutional state in painful processes of complex and partly undirected restructuring in reaction to external as well as internal threats and shocks. These processes make way for new contradictions, and the 'morbid symptoms' that appear 'when the old is dying and the new cannot be born'. ${ }^{141}$ In such a context, European law - and the national law that is synthesises - will inevitably appear disordered and in disarray. The challenge to OMT is a judicial microcosm of this dynamic disequilibrium and the wider conflicts it reflects.

Even if recent events rapidly accelerate a legitimacy crisis that had been in the making for nearly a decade, symbolised by the failure of the Constitutional project on which much European political capital was expended, these underlying tensions must be grasped. They expose the limits of any narrow conception of legality, or legal or moral normativism for the constitutional self-understanding of Europe and its constitutional evolution, as normative ordering is increasingly subject to the imperatives of political, constitutional and economic power.

If it had been thought that EMU could function on the basis of 'governance without government', substituting politics for the routines of administration and the rule of European law, and ostensibly removing the political character of decision-making, crisis has obliterated any such ambition. It has also called into

\footnotetext{
140 See Wood, above note 135 , at 26.

141 'The crisis, as Gramsci described in an earlier age, 'consists precisely in that the old is dying and the new cannot be born; in this interregnum a great variety of morbid symptoms appear.' Antonio Gramsci, Selections from the Prison Notebooks (1971) 556. This has been magisterially outlined in the conditions of late democratic capitalism by Streeck, above note 134 .
} 
question the principles of constitutional integrity and political equality on which any functional and legitimate Union must ultimately rest.

These characteristics of integration - in short, the absence of a constitutional equilibrium or the political will and capacity to nurture one - combine in such a way that the dynamic relation between constitutional power and constitutional authority, fact and norm now suggests a highly dysfunctional process. Facts about power and capacity are being translated into norms and principles that structure and inform the integration process in a way that is causing deep problems of legitimation, as evidenced by an increasing backlash against the EU, in all Member States, small and large, core and periphery. ${ }^{142}$

\section{CONCLUSION}

With the OMT reference, the logics of supranational economy, Westphalian state power and domestic constitutional authority have finally, if only yet potentially, come into a direct conflict in the judicial domain. This presents the ECJ with a serious dilemma: either undermine the European Central Bank and its currency that is apparently so central to the project of integration and the political class that has staked its future on it, or confront the German Constitutional Court and a domestic constitution that symbolises the achievements of the post-War democratic Rechtsstaat.

Whether the OMT programme was economically sound or politically prudent is of course moot and will depend upon the wisdom of macro-economic policy choices and longer-term institutional and geo-political shifts of power in Europe. There are plenty of reasons to be sceptical; not least due to the lack of a panEurope democratic mandate to legitimise measures with potentially significant redistributive implications; at the very least, it seems, the assumption of some risk for other states' financial liabilities. ${ }^{143}$ Such a transformation of the EU from a regulatory into a redistributive state, but in a technocratic way, sotto voce, behind the backs of the electorates - if that is the cumulative impact of the post-crisis measures such as OMT -, is likely to fuel resentment and populist backlash, both in creditor as well as debtor states. ${ }^{144}$

But if the 'normal' distinction between economic and monetary policy, which is central to the ruling of the German Court, breaks down in times of financial

\footnotetext{
${ }^{142}$ For an exploration of this phenomenon in the 'new democracies' in Central and Eastern Europe, see P. Blokker, New Democracies in Crisis: A Comparative Constitutional Study of the Czech republic, Hungary, Romania and Slovakia (Routledge, 2013).

143 Paul De Grauwe argues that at no point could the implementation of the OMT programme directly affect tax payers of Members States, even in the case of default, although it does raise the risk of inflation and moral hazard, 'Why the European Court of Justice Should Reject the German Constitutional Court's Ruling on OMT' (2014) EUROPP blog, accessible here: http://bit.ly/1hDwlFX.

144 See e.g. D. Chalmers, 'The European Redistributive State and a European Law of Struggle' (2012) European Law Journal 667 - 693.
} 
crisis and emergency, this must be handled sensitively. Although the Court may not be the right institution to determine the legitimacy of suspending normal procedures in abnormal times, in circumstances of what might be termed 'alegality', it might therefore be prudent to approach it with caution. ${ }^{145}$

The OMT judgment illuminates the special responsibility of the judicial role in the European constitutional architecture, with national and European courts having to balance issues of complex equality of persons and of states in a context of increasing economic and political imbalances between nations. The ECJ has its work cut out.

But if for the German court the logic of European integration is predominantly based on imperatives of competitiveness and market logic and where from this perspective the OMT measure comes up short, for the ECJ, on the contrary, this can present but one facet of the broader European constitutional logic and value of integration against which OMT must be judged. This more expansive evaluation must include not only imperatives of competitiveness and market logic, but also of peace, prosperity, and solidarity between nations and peoples. The OMT may fail this more holistic test too, but only in posing it in its full context, can a Court properly discharge its constitutional duty.

For a national court, it is one thing to assert the inviolability of fundamental rights and their centrality to national constitutional identity, quite another to impose an ordo-liberal logic of fiscal discipline and austerity and insist on this visa-vis other member states' populations, even if dressed up in the 'right to vote' of German citizens. ${ }^{146}$ But by assuming that the only reason for higher yields after the crisis hit could be Mediterranean profligacy rather than a lack of pan-European solidarity, and that only the only response to this profligacy can be a strict 'conditionality', potentially jeopardised by OMT, this is the effect of the court's judgment.

In challenging the supranational logic of formal hierarchy and legitimate action or government 'from above', the German Court is in danger of giving its implicit stamp of approval to a different, but no less problematic, informal logic of hierarchy and coercion:

The coercion implicit in the austerity programme prescribed by Germany has meant that equitable participation has been side-lined and replaced with increasing frequency by forms of hierarchical dependency. By linking credits to rigorous reforms and the corresponding control mechanisms, entire regions have been plunged into social decline and countless people have been

145 On 'alegality', see H. Lindahl, above note 100. From this perspective, the law temporarily suspends political and economic disorder (rather than the political temporarily suspending legal order). As Lindahl's analysis suggests, putting things that way around might be more fruitful, i.e. suggesting disorder is the dominant category.

${ }^{146}$ Even if it is a logic that has been accepted by the ECJ itself in Pringle, above note 17. 
deprived of livelihoods, their dignity, their future - and, not least their faith in Europe. ${ }^{147}$

Sometimes, as the Marx brothers understood, it is prudent to stay quiet. ${ }^{148}$ In ignoring this advice, the German court has intimated that 'durchwursteln' is no longer a viable option for European integration. They may well be right. There are additional reasons for thinking that a conjuncture has been reached in the EU, which extend beyond the difficulties in dealing with the economic troubles in the Eurozone countries. ${ }^{149}$

To the German court, however - and to the ECJ -, it must be noted that friendliness towards European law is superfluous in the absence of any friendliness to the conditions of possibility of European law; namely a relatively harmonious community of peoples, for whom co-operation as much as competition must be a way of life. To take seriously the conditions of possibility of European law is to take seriously issues of complex equality between states and persons. The German Court alone is not equipped to see through this task; but, with guidance from the ECJ it can play its part to ensure that inequalities in economic and political power are not aggravated by discrete and parochial exertions of constitutional power.

\footnotetext{
147 Beck, above note 35 , at $62-63$.

148 This is the message conveyed by the two dissenting judges, Lübbe-Wolff and Gerhardt.

149 The political and constitutional situation in Hungary, for example, with its rise in authoritarian nationalism and constitutional mutation and the EU's inability to deal with it has been identified as suggesting a qualitative shift in the EU's raison d'être. This is the view of J-W Müller, 'Beyond Militant Democracy?' (2012) New Left Review. See also M. Dani, ‘The Partisan Constitution' (2014) LEQS. On the relation between Hungary's turn to authoritarianism and European integration see e.g. P. Blokker, above note 142 .
} 